\author{
MAREK KOS ${ }^{1,2}$, AGNIESZKA DZIEWA ${ }^{2}$, ANNA KSYKIEWICZ-DOROTA ${ }^{3}$, \\ BARTŁOMIEJ DROP ${ }^{1}$, MICHAŁ KOS ${ }^{4}$
}

\title{
Nursing care quality and post-operative wound infections
}

\begin{abstract}
Introduction. The aim of the surveillance over infections is to define the critical points, lacks in knowledge or staff skills, as well as lack of equipment. It is aimed at preventing the same mistakes from being conducted all over again, instead of making those guilty suffer from consequences of their mistakes.

Aim. The authors aimed at assessing the quality of nursing care procedures in terms of preventing post-operative wound infections.

Materials and methods. The research was conducted in medical treatment, surgical and intensive care ward. A self-constructed questionnaire "Nursing care quality and prophylaxis of hospital-acquired infections" was used for the study. It was validated using the peer judges method.

Results and conclusions. The highest nursing care coefficient was noted in county hospitals $(\bar{X}=94.5 \%)$, while the lowest was noted in clinical hospitals $(\overline{\mathrm{X}}=91.3 \%)$. It was concluded that there is a deficit in adherence to procedures related to post-operative wound treatment.
\end{abstract}

Keywords: prevention of hospital-acquired infections, postoperative wound infections.

DOI: $10.1515 /$ pjph-2016-0003

\section{INTRODUCTION}

The assessment of nursing care quality should not be carried out without considering the overall quality of medical services provided by all healthcare employees. The staff should be committed not only to provide quality care but also treat the best patients' interest as a value of high quality. Doctors swear to abide by the Hippocratic Oath which includes the primum non nocere rule - this is one of the first statements proving that medical professionals care about the quality of the services they provide. Not that long ago, the quality of healthcare services was perceived to be a variable dependent on the conditions in which medical care units are operating. It was then considered as having the highest quality medical devices which was tantamount to huge spending on these. Gradually though, most attention started to be paid to the actual quality of medical services [1]. The World Health Organization assumes that one's right to stay in the best health, as well as having access to the best healthcare are the basic rights of every human being. On the one hand, this means that everybody should gain access to medical care but on the other hand, the services should be of the best quality possible. Providing high quality care means the need for showing the differences between the desired quality and the quality that was really achieved, which obviously means that there is a need for analyzing the reasons of low quality of care and improvement.
Hospital-acquired infections are a serious medical, financial and legal problem. They are related to the way that hospitals all around the world operate and they pertain to both hospitals of the lowest referential levels and highly specialized clinics, which means that they are one of the most serious problems of today's medicine. These problems often cause unnecessary suffering, they deteriorate the underlying disease, make the hospitalization process longer and increase the treatment costs [2-4].

Hospital-acquired infections are closely related to invasive diagnostic and treatment methods, as well as biological features of the patients or the way healthcare staff work. Supervising hospital-acquired infections is regarded as the most important quality criterion in hospital management.

At the moment, hospitals are expected to operate in a way that generates the lowest costs possible. This means, costs of treating hospital-acquired infections are one of the main factors influencing the decision about hospital funding [5].

\section{AIM}

The authors aimed at assessing the nursing care quality, in terms of the prophylaxis of postoperative infections.

\footnotetext{
${ }^{1}$ Department of Public Health, Medical University of Lublin, Poland

${ }^{2}$ Independent Public Health Care Unit in Kraśnik, Poland

${ }^{3}$ Faculty of Nursing and Health Sciences, Medical University of Lublin, Poland

${ }^{4}$ Student Research Society, II Faculty of Medicine with the English Division, Medical University of Lublin, Poland
} 


\section{MATERIAL AND METHODS}

The study was conducted in 9 hospitals in the following regions: Lublin Voivodeship, Podkarpackie Voivodeship and Lesser Poland Voivodeship. The heads of the hospitals and the nurses working in these hospitals issued written consents for the study to be conducted.

The research was done in:

- 3 county hospitals: Independent Public Health Care Units in Łuków, Włodawa and Kraśnik,

- 3 provincial hospitals: Cardinal Stefan Wyszyński Regional Specialist Hospital in Lublin, Jan Boży Autonomous Public District Hospital in Lublin, Jadwiga of Poland Voivodship Hospital in Rzeszów,

- 3 clinical hospitals: Autonomous Public Teaching Hospital No. 1 in Lublin, Autonomous Public Teaching Hospital No. 4 in Lublin, as well as University Hospital in Cracow.

Overall, the study was done in 56 hospital wards, out of which 27 were medical treatment facilities, 20 were medical treatment wards, and 9 intensive care units. Some 450 care procedures were conducted, 50 in every hospital.

A self-constructed questionnaire "Nursing care quality and prophylaxis of hospital-acquired infections" was validated using the peer judges method. The criteria used in the questionnaire described the care activities that prevent hospitalacquired infections from development, paying attention to particular organs or structures. The authors were inspired by a sheet named BOHIPSZO - it was a tool used assessing the overall quality of nursing care. The questionnaire used by the authors of this study contained nine main criteria (IX) and 83 detailed criteria (overall, there were 349 points). The sheet contained three options to be chosen from, namely: Yes, No, Not applicable. The Yes column was used for checking whether the certain criterion applied to what it was like in reality.
The No column included the weight of the statistical significance in case any discrepancies were found. The Not applicable column included the weight of a criterion that had no reference to a certain ward or patient. In case the criterion was true to some extent only, the answer could be divided between Yes and No. Later, the care coefficient for particular wards was also assessed - it was a relationship between the value of the expected care and real care

\section{RESULTS}

The procedures related to the prophylaxis of hospital-acquired infections are most frequently conducted in medical treatment facilities due to the type of patients admitted or the type of medical services provided. In most cases, the criterion Prophylaxis of postoperative wound elicited the Not Applicable answer. This was due to the fact that no operational procedures were provided. Despite that, in case of medical treatment wards, some important surgical procedures provided to be important, like surgical debridement of bed sore, care of arteriovenuous fistula, checking lymph nodes, etc. Most answers that were provided concerned the ways of eliciting the plaster material and dividing the patients into those with clean or infected wounds.

In case of medical treatment wards in regional hospitals, most problems concerned criterion 1 - The patients who are being prepared for treatment have their bed linen changed - $81.6 \%$ (statistically significant differences $\alpha=0.02$ ), Bed linen is changed at least every 72 hours or when it is needed (2) $-90.1 \%$ and In the evening preceding the operation and during the day of the operation, the patient takes a bath or a shower (4) $-90.5 \%$ (Table 1 ). For criteria 2 and 4 , these differences were not statistically significant $(\alpha=1.00$ and $\alpha=0.13)$. In case of medical treatment wards, the lowest care coefficient was achieved in case of criterion 7 - Patients with infected

TABLE 1. Post-operative wound infection prophylaxis in surgery and medical treatment wards in hospitals at all referential levels.

\begin{tabular}{|c|c|c|c|c|c|c|c|c|c|c|}
\hline \multirow{4}{*}{ Detailed criteria } & \multicolumn{10}{|c|}{ Wards } \\
\hline & \multicolumn{5}{|c|}{ surgical } & \multicolumn{5}{|c|}{ medical treatment } \\
\hline & \multicolumn{5}{|c|}{ W.O.P. } & \multicolumn{5}{|c|}{ W.O.P. } \\
\hline & $\mathbf{K}$ & $\mathbf{W}$ & $\mathbf{P}$ & $\chi^{2}$ & $\alpha$ & $\mathbf{K}$ & $\mathbf{W}$ & $\mathbf{P}$ & $\chi^{2}$ & $\alpha$ \\
\hline \multicolumn{11}{|l|}{ IV. Post-operative wound infections prophylaxis } \\
\hline 1. The patients who are being prepared for treatment have the bed linen changed & 93.6 & 88.9 & 81.6 & 5.78 & 0.02 & 88.9 & 72.2 & 100.0 & 2.52 & 0.11 \\
\hline 2. Bed linen is changed at least every 72 hours or when it is needed & 96.6 & 95.5 & 90.1 & 0.00 & 1.00 & 91.3 & 92.3 & 90.5 & 0.00 & 1.00 \\
\hline $\begin{array}{l}\text { 3. Wound dressings are made of sterile materials, bought in pharmacies } \\
\text { or sterilized prior to the surgery }\end{array}$ & 98.5 & 98.2 & 99.4 & 0,00 & 1.00 & 97.7 & 100.0 & 96.7 & 0.46 & 0.50 \\
\hline $\begin{array}{l}\text { 4. In the evening preceding the surgery and during the day of the surgery, } \\
\text { the patient takes a bath or a shower }\end{array}$ & 97.9 & 94.4 & 90.5 & 2,35 & 0.13 & 88.9 & 89.3 & 100.0 & 4.00 & 0.046 \\
\hline 5. Patients have their hair removed in the operating field & 94.7 & 97.2 & 97.4 & 0.00 & 1.00 & 84.6 & 100.0 & 100.0 & 0.00 & 1.00 \\
\hline 6. Patients' hair is cut on the day of the surgery & 77.8 & 85.6 & 93.1 & 6.67 & 0.01 & 78.6 & 76.0 & 100.0 & 2.25 & 0.13 \\
\hline 7. Patients with infected wounds are all kept in one room & 76.6 & 83.6 & 93.9 & 1.99 & 0.16 & 63.2 & 84.3 & 83.3 & 1.83 & 0.18 \\
\hline 8. The wound dressing is changed when the wound excretes some substances & 98.2 & 95.0 & 92.8 & 0.25 & 0.62 & 96.4 & 100,0 & 98.7 & 0.00 & 1.00 \\
\hline Mean \% $(\bar{X})$ & 91.7 & 92.3 & 94.4 & & & 86.2 & 89.3 & 96.2 & & \\
\hline Overall $\bar{X}$ & & & 92.8 & & & & & 90.6 & & \\
\hline$\chi^{2}$ & & & 60.14 & & & & & 24.56 & & \\
\hline$\alpha$ & & & 000000 & & & & & 0.00091 & & \\
\hline
\end{tabular}


wounds are kept in one room $-84.3 \%$ (this is not significant statistically). In county hospitals, a higher overall nursing care coefficient was achieved in case of medical treatment wards $(\bar{X}=96.2 \%)$ than surgical wards $(\bar{X}=94.4 \%)$.

An analysis of the results achieved in hospitals of the second referential level made it possible to determine the most problematic areas in nursing care of treating infected postoperative wounds. Some of the basic nursing activities were done improperly, particularly in case of The patients who are being prepared for treatment have the bed linen changed (1) - 88.9\%, Patients with infected wounds are kept in one room (7) $-83.6 \%$, Patients' hair is cut on the day of the operation (6) $0-85.6 \%$. For criteria 1 and 6 , these differences were significant statistically and they were, respectively $\alpha=0.02$ and $\alpha=0.01$. In case of medical treatment wards in regional hospitals, the lowest care coefficient was reported for criterion $1-72.2 \%$ (not statistically significant).

When it comes to clinical hospitals, most deficits were reported in case of the following criteria Patients' hair is cut on the day of the operation (6) $-77.8 \%$ and Patients with infected wounds are kept in one room (7) $-76.6 \%$ (the difference is significant statistically $(\alpha=0.01)$ and they were reported in clinical wards. Also, in case of treatment wards, most deficits were noticed in case of criterion 7 -Patients with infected wounds are kept in one room (7) $-63.2 \%$ (no statistically significant differences.)

In case of surgical wards, some statistically significant differences were found for criteria 1 and $6(\alpha=0.02$ and $\alpha=0.01$, respectively) and in treatment wards it was criterion $4(\alpha=0.046)$. The overall care coefficient turned out to be higher in surgical wards $(\bar{X}=92.8 \%)$ than in treatment wards $-90.6 \%$ (Table 1$)$. These were statistically significant differences: $\alpha=0.00000001$ and $\alpha=0.00091$, respectively.

Judging by the hospital records, it was estimated that postoperative complications, like infections of both the wound

TABLE 2. Number and coefficient of post-operative wound infections, abdomen and surgical site in relation to the overall number of infections.

\begin{tabular}{|c|c|c|c|c|c|c|c|c|c|c|}
\hline \multirow{4}{*}{$\begin{array}{c}\text { Type } \\
\text { of infection }\end{array}$} & \multicolumn{10}{|c|}{ Hospitals } \\
\hline & \multicolumn{4}{|c|}{ regional } & \multicolumn{6}{|c|}{ district } \\
\hline & \multicolumn{2}{|c|}{ 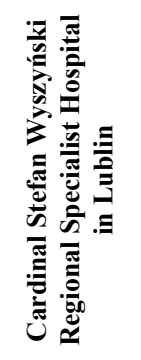 } & \multicolumn{2}{|c|}{ 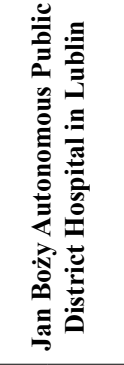 } & \multicolumn{2}{|c|}{ 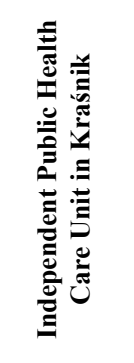 } & \multicolumn{2}{|c|}{ 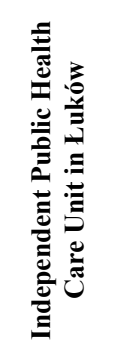 } & \multicolumn{2}{|c|}{ 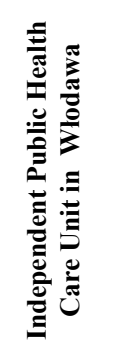 } \\
\hline & $\mathbf{n}$ & $\%$ & n & $\%$ & $\mathbf{n}$ & $\%$ & n & $\%$ & $\mathbf{n}$ & $\%$ \\
\hline $\begin{array}{l}\text { Overall } \\
\text { number } \\
\text { of infections }\end{array}$ & 325 & 100.0 & 30 & 100.0 & 132 & 100.0 & 63 & 100.0 & 8 & 100.0 \\
\hline $\begin{array}{l}\text { Post-operative } \\
\text { wounds } \\
\text { infections }\end{array}$ & $\mathrm{n} / \mathrm{a}$ & $\mathrm{n} / \mathrm{a}$ & 0 & 0.0 & 37 & 28.0 & 0 & 0.0 & 0 & 0.0 \\
\hline $\begin{array}{l}\text { Infections of } \\
\text { the abdomen }\end{array}$ & $\mathrm{n} / \mathrm{a}$ & $\mathrm{n} / \mathrm{a}$ & 0 & 0.0 & 2 & 1.5 & 0 & 0.0 & 0 & 0.0 \\
\hline $\begin{array}{l}\text { Surgical site } \\
\text { infections }\end{array}$ & $\mathrm{n} / \mathrm{a}$ & $\mathrm{n} / \mathrm{a}$ & 5 & 16.7 & 1 & 0.8 & 30 & 47.6 & 0 & 0.0 \\
\hline
\end{tabular}

Source: Data elicited from infection documentation in the hospitals that were looked at $(\mathrm{n} / \mathrm{a}$ - data not available) and surgical site constituted an important fraction of all infections (Table 2). These infections mainly happen to patients of the treatment wards, being the most common type of infection (surgical ward $-32.6 \%$, gynecology and obstetrics $-26.7 \%$ ) as well as intensive therapy patients, subject to surgical procedures (Table 3).

Table 4 shows the value of value of care coefficient matched with the prophylaxis of post-operative wounds infections, which shows statistically significant differences regarding particular hospitals. The best results were achieved by hospitals of the first referential level ( $\bar{X}=94.5 \%)$, district hospitals ( $\bar{x}=91.9 \%$ ) and clinical hospitals gained $91.3 \%$. These were statistically significant differences $(\mathrm{H}=0.00012)$.

\section{DISCUSSION}

The number of infections of post-operative wounds is one of the factors that determine the overall assessment of nursing care quality, particularly in case of surgical wards. Hence,

TABLE 3. Number and coefficient of post-operative wound infections in patients of surgery and intensive therapy wards.

\begin{tabular}{|c|c|c|c|c|c|c|}
\hline \multirow{4}{*}{ Infection type } & \multicolumn{6}{|c|}{ Ward } \\
\hline & \multirow{2}{*}{\multicolumn{2}{|c|}{$\begin{array}{l}\text { Intensive } \\
\text { therapy }\end{array}$}} & \multicolumn{4}{|c|}{ surgery wards } \\
\hline & & & \multicolumn{2}{|c|}{ surgical } & \multicolumn{2}{|c|}{$\begin{array}{l}\text { gynecology } \\
\text { and obstetrics }\end{array}$} \\
\hline & $\mathbf{n}$ & $\%$ & $\mathbf{n}$ & $\%$ & $\mathbf{n}$ & $\%$ \\
\hline $\begin{array}{l}\text { Overall number } \\
\text { of infections }\end{array}$ & 163 & 100.0 & 135 & 100.0 & 30 & 100.0 \\
\hline $\begin{array}{l}\text { Post-operative } \\
\text { wounds infections }\end{array}$ & 2 & 1.2 & 35 & 25.9 & 0 & 0,0 \\
\hline $\begin{array}{l}\text { Infections } \\
\text { of the abdomen }\end{array}$ & 2 & 1.2 & 0 & 0.0 & 0 & 0.0 \\
\hline Surgical site infections & 19 & 11.7 & 9 & 6.7 & 8 & 26.7 \\
\hline
\end{tabular}

Source: Data elicited from hospital records concerning infections

TABLE 4. The value of nursing care quality coefficient in terms of surgical site infections in selected hospitals.

\begin{tabular}{|c|c|c|c|c|c|c|c|c|c|c|}
\hline & \multicolumn{10}{|c|}{ "Hospitals } \\
\hline & \multicolumn{3}{|c|}{ clinical } & \multicolumn{3}{|c|}{ regional } & \multicolumn{3}{|c|}{ county } & \multirow[b]{2}{*}{$\begin{array}{l}\overline{\bar{T}} \\
\overline{0} \\
0 \\
0\end{array}$} \\
\hline & $\mathbf{A}$ & B & C & D & $\mathbf{E}$ & $\mathbf{F}$ & G & I & $\mathbf{J}$ & \\
\hline $\mathrm{N}$ & 34 & 34 & 45 & 43 & 36 & 25 & 40 & 37 & 42 & 336 \\
\hline SD & 16.80 & 8.27 & 8.37 & 9.04 & 15.64 & 13.23 & 8.84 & 14.36 & 10.70 & 12.14 \\
\hline W.O.P. & 85.9 & 95.8 & 92.3 & 94.6 & 90.4 & 90.7 & 97.5 & 94.1 & 91.8 & 92.7 \\
\hline$\overline{\mathrm{X}}$ & & 91.3 & & & 91.9 & & & 94.5 & & \\
\hline $\mathrm{p}<0.05$ & & & & & $\mathrm{H}=0.0$ & 0012 & & & & \\
\hline
\end{tabular}

Key:

$\mathrm{N}$ - number of measurements

W.O.P. - nursing care quality coefficient (\%)

SD - Standard Deviation $\mathrm{H}$ - Kruskal-Wallis Test

A - University Hospital in Cracow

B - Autonomous Public Teaching hospital in Lublin

C - Autonomous Public Teaching Hospital No. 4 in Lublin

D - Jadwiga of Poland Voivodeship Hospital in Rzeszów

E - Cardinal Stefan Wyszyński Regional Specialist Hospital in Lublin

F - Jan Boży Hospital in Lublin

G - Independent Public Health Care unit in Kraśnik

I - Independent Public Health Care unit in Łuków

$\mathbf{J}$ - Independent Public Health Care unit in Włodawa 
a necessity of introducing and adhering to the rules of prophylaxis of post-operative wound infections. It goes without saying that even a surgical procedure that was made in the best way can be affected by incorrect care and not adhering to rules of prophylaxis.

Preventing surgical site infections is an important issue, both in rich and poor countries. At least in 3\% of the patients undergoing clean surgeries and $30 \%$ of those undergoing septic or dirty surgery develop a surgical site infection [6-8].

The findings of the author of the dissertation show that in the wards that were looked at, the staff did not adhere to the rules about changing the bed linen $(7.3 \%)$. Hence, there might be a risk that microorganisms may infect the wound, even though adhering to the most basic rules of hygiene like hand washing or taking showers can remove up to $80 \%$ of these microorganisms. The findings of the study show that in case of some $6.5 \%$ of the patients, these procedures are not adhered to.

The frequency of post-operative wound infections is closely related to the type of surgery. The percentage of infections of these wounds might differ for various types of surgeries, according to American College of Surgeons. A fixed rate of microorganism infections is around $2 \%$, while the percentage of infections in case of clean-contaminated surgeries hovers between 2.8 and $11 \%$, in case of infected surgeries it is $20 \%$ while in case of dirty surgeries it is $40 \%$ [9].

The research done by the author of the study shows that in some $19.2 \%$ of cases, the patients with infected wounds and those with clean wounds are kept in one room, which boosts the risk of cross infections and microorganism transfers. Using wound dressings in the right way can improve the prophylaxis of surgical site infections. As it turned out, in some $1.9 \%$ of cases in medical treatment wards, no sterile wound dressings were used, while in case of $1.6 \%$ of patients, the staff did not apply fresh dressings, even if they were dirty with blood or the substances secreted by the wound. In case of surgical wounds, these indexes were 1.3 and $4.7 \%$ respectively

According to the guidelines issued by the American Food and Drug administration, skin preparation before surgery should lower the level of the bacteria in the body [10]. Holtz and Wenzl in their literature review have noticed that in case of $20-70 \%$ of post-operative infections happen after the patient has been discharged from the hospital. These infections are more likely to happen to patients who have "clean" wounds and those with short hospitalization period [11].

Ayliffe et. al. have researched the spread of infections and they found a relationship between patient's age and infections. There are also other factors affecting it: the length of patient's stay in the hospital, gender, surgical treatment and antibiotic therapy. The surgical site infections were looked at and the wounds were divided into clean, clean-contaminated or contaminated wounds, no matter whether any drainage had been used or not. The frequency of infections in the above-mentioned studies was $10.4 \%$ [12].

The authors conducted their own research which revealed that there is no simple relationship between the cleanliness of the operating field and the frequency of infections. It might not be surprising that some $40 \%$ of infections happen after surgeries in contaminated field, yet some $25 \%$ happen in clean field, which may suggest incorrect handling of the procedures.

Back in 1960s, Bóbr supervised a study that provided data concerning the frequency of hospital-acquired infections in different hospital wards, including surgery wards. Overall, the infection incidence was $6.9 \%$ on average. The number of person-days in the ward after the procedure has been done increased up to $7 \%$. The researchers have also looked at risk factors related to operating procedures (wound drainage, the order of procedures) and their influence over the frequency of post-operative wounds [13].

The authors' own research shows that incorrect preparation of the operating theater is one of the main risk factors. In $4.4 \%$ of cases, this pertained to shaving the hair instead of cutting them, as well as doing this during the day before the surgery $(14.8 \%)$. Doing so can also cause some inflammatory changes or skin micro-damage.

Invasive treatment methods also pose a high infection risk and they require some special precautions to be taken, prior to the surgery, as well as during the procedure and later on.

In case of infections of surgical wounds, it is the physiological bacterial flora that causes it. This means, it is of utmost importance to prepare the patient's skin prior to the surgery, as it would reduce the number of microorganisms. In many countries, patients take a bath or a shower with some antiseptic liquid prior to the surgery and it lowers the number of bacterial colonies. CDC also recommends the actions mentioned above as a way to lower the risk of post-operative wound infection [14].

Too much hair makes both the surgery and post-operative care much harder. Also, it boosts the infection risk and deteriorates the wound healing process. Currently, there are three methods of removing the hair: shaving (the most dangerous method - it may cause skin micro-damages), using depilating creams (they may cause an allergy, they should not be used on the mucous membrane), hair clipping. CDC recommends avoiding hair removal or removing it using electronic hair clippers. Clinical research shows that skin healing process means an increased number of infected wounds (3.1-20\%), when compared with other hair removal methods [15].

Some other research shows that traditional incise drapes are less effective than antimicrobial incise drapes [16].

A team supervised by Wójkowska-Mach have analyzed some data concerning post-operative infections, gathered between 2000-2003 in over 600 hospitals located in ten European countries: Belgium, Finland, France, Greece, Spain, The Netherlands, Lithuania, Germany, Poland, Great Britain. Polish hospitals fared very well when it comes to care quality in microbiological supervision. In all cases of post-operative wounds a microbiological examination looking at etiological factors and in $87 \%$ of cases, drug resistance was noticed [17].

Research conducted by Harvard Medical School [18] on a randomly chosen group of inpatients has shown that surgical site infections are one of the most common infections among surgical patients. It also ranked second in the overall pool of hospital-acquired infections (only the urogenital infections were more frequent).

Research conducted in the Netherlands in 1996 has shown that the index of the surgical site infections can vary, depending on the type of procedure or hospital. Patients operated in university hospitals are at a higher risk of surgical site infections than in hospitals of other types. A higher number of operations during one year has shown a reduction of the infection risk. Also, improved supervision of infections has greatly reduced the risk for patients - four years after the supervision activities were commenced, the risk was greatly reduced, when compared to the first year. Later on, in the fifth year, the risk has diminished even further. 
The activities aiming at reducing the number of infections included: improving the discipline in the ward, changing the materials used, care for post-operative wounds, transporting the patient and materials, disinfection, sterilization, antibiotics and anticoagulant policies [19].

Post-surgical wound infections still remain a serious problem, since they hugely influence the morbidity and mortality among the patients. According to the Polish National Association for Hospital Infections, surgical site infections constitute some $14 \%$ of hospital-acquired infections and $35 \%$ of all infections reported on medical treatment wards. Most of these cases are patients that had been treated on the wards. Since there is an overall tendency to discharge patients earlier, doctors may not put the infections that usually happen later in their records [20].

In the hospitals that were looked at, the rate of post-operative infections reached $16.7 \%$ to $47.6 \%$ of the overall infection rate, while in case of surgical wards, it was $26.7 \%$ to $32.6 \%$. Not adhering to the rules of preventing hospital-acquired infections usually concerns preoperative procedures being conducted improperly. Care deficit reached $13.8 \%$ in one of the clinical hospitals.

The first Polish conference about hospital-acquired infections and ways to prevent them was held in 1981. The works presented during the conference that regarded hospital acquired infections suggest that some $11.9 \%$ of patients hospitalized on surgical wards. Also, some etiological factors that cause these infections were identified - anaerobic bacterial flora constitutes some $24 \%$ of bacterial flora in all post-operative wounds [2].

A research study conducted in 2001 and 2002 in County Hospital in Oświęcim shows that in the following wards conducted active surveillance of healthcare-acquired infections: surgery, orthopedics, pediatric surgery, gynecology and obstetrics, intensive care units and operating block - overall, some 171 beds (32.8\% of all beds in the hospital). In 2001, passive surveillance revealed $71.4 \%$ "Infection cards" among patients treated in the surgical ward. A year later, in 2002, active surveillance revealed much more cases - from 37 in 2001 to 50 in 2002. Hence, the morbidity coefficient was $2.32 \%$ and $3.82 \%$, respectively. Thanks to active surveillance, the detection rate increased over $130 \%$ [21].

The risk of surgical site infections is closely related to bacterial infections affecting post-operative wounds. Foreign authors claim that infections of that sort usually prolong the patient's hospital stay for seven days and boost the treatment costs, so that they exceed 3000 dollars. When taking the American perspective into account, it means that some additional 5 million dollars need to be spent every day which translates into another 2 billion dollars annually. It is estimated that some 27 millions of surgical procedures are conducted yearly in the US. Surgical site infections are the most frequent infections that happen to surgical patients - they are estimated to happen at the rate of $38 \%$ and they also rank as third in the general statistics of hospital-acquired infections - they constitute some $14-16 \%$ of these infections. It is estimated that surgical site infections are one of the main causes of some 10.000 deaths every year [22].

Increased costs of medical care and introducing outpatient surgery made hospital stays much shorter and they increased the number of surgical procedures conducted during one day. The findings of a prospective examination of post-operative wounds in patients treated during one day revealed that some $6.7 \%$ of them suffered from infections. The infection happened in some $41 \%$ of the inpatients and to $59 \%$ of inpatients [12].

Even though surgical site infections remain the second most common infection in surgical wards, they are one of the most precise ways to assess the quality of work, since there is a direct relationship between these wounds and the surgical procedures. In Denmark, some $0.5 \%$ of the whole budget spent on hospitals is constituted by the costs related to treating surgical site infections. A study that was done in the United Kingdom revealed that surgical site infections happened to some $4 \%$ of all surgical patients, which stands for $1 / 3$ of all hospitalacquired infections [11]. In Europe, the frequency of surgical site infections hovers from 1.5 to $20 \%$ of all surgery infections. Due to this ailment, the average hospital stay is longer - 9.8 days on average and the treatment costs increase as well - from 1860 to 4040 EUR for 1 patient.

It is estimated that there are around 450 to 600000 cases of surgical site infection in countries of the European Union. This means, the overall cost of treating it hovers between 1.47 to 19.1 trillion Euro. Some $38 \%$ of patients affected by it, die during the postoperative period in the surgical wards [23].

\section{CONCLUSIONS}

1. There is a $7 \%$ deficit when it comes to adhering by the procedures of preventing surgical site infections

2. Any failures in this field are related to incorrect preparation of the operating field, dividing patients with clean and contaminated wounds, patients' personal hygiene and cleanliness of the bed linen.

\section{REFERENCES}

1. Fleischer M, Bober-Gheek B. Podstawy pielęgniarstwa epidemiologicznego. Warszawa: Centrum Kształcenia Podyplomowego Pielęgniarek i Położnych; 2006.

2. Dzierżanowska D. Zakażenia szpitalne. Bielsko-Biała: ó- medica press; 2008.

3. Heczko P, Wójkowska-Mach J. Zakażenia szpitalne; podręcznik dla zespołów kontroli zakażeń szpitalnych. Warszawa: Wyd. Lekarskie PZWL; 2009.

4. Jabłoński L, Karwat ID. Podstawy epidemiologii ogólnej, epidemiologia chorób zakaźnych. Lublin: Wydawnictwo Czelej; 2002.

5. Garus-Pakowska A, Szatko F, Pakowski M. Aspekty prawne odpowiedzialności zakładów opieki zdrowotnej za zakażenia szpitalne. Med Pr. 2009;60(4):335-43.

6. Anderson DJ, Chen LF, Sexton DJ, at al. Complex Surgical Site Infections and the Devilish Details of Risk Adjustment: Important Implications for Public Reporting. Infect Control and Hosp Epidemiol. 2008;29(10):234-9.

7. Astagneau P, Lhasriteau F. Surveillance of surgical-site infections: impact on quality of care and reporting dilemmas. Curr opin Infect Dis. 2010;23(4):306-10.

8. Casey AL, Elliott TSJ. Progress in the prevention of surgical site infection. Curr Opin Infect Dis. 2009;22:370-5.

9. Florman S, Nichols LR. Current approaches for the prevention of surgical site infections. Am J Infect Dis. 2007;3(1):51-61.

10. Wilson J, Wared VP, Coello R, at al. A user evaluation of the Nosocomial Infection National Surveillance System: surgical site infection module. J Hosp Infect. 2002;52:114-21.

11. Leaper DJ, van Goor H, Reilly J, at al. Surgical site infection - an European perspective of incidence and economic burden. Int Wound $\mathrm{J}$. 2004; 1:247-73.

12. Graf K, Ott EE, Vonberg RP, at al. Surgical site infections-economic consequences for the health care system. Langenbecks Arch Surg. 2011;396:453-9. 
13. Bulanda M, Tyski S, Ciuruś M. Zakażenia szpitalne w Polsce - stan wiedzy na kwiecień 2011. Raport programu „Stop Zakażeniom Szpitalnym. Program Promocji Higieny Szpitalnej"; 2011

14. Centers for Disease Control and Prevention: Guidance on Public Reporting of Healthcare - Associated Infections. Recommendations of the Healthcare Infection Control Practices Advisory Committee; 2005.

15. Mangram AJ, Horan TC, Pearson ML, at al. The Hospital Infection Practices Advisory Committee. Guideline for prevention of surgical site infection 1999. ICHE. 1999;20(4):247-78.

16. Astagneau P, Lhasriteau F. Surveillance of surgical-site infections: impact on quality of care and reporting dilemmas. Curr opin Infect Dis. 2010;23(4):306-10.

17. Wójkowska-Mach J, Suetens C, Leat C, at al. Zakażenia miejsca operowanego w polskich szpitalach i europejskim programie HELICS. Zakażenia. 2005;2:70-3.

18. Pankin HT. Kontrola zakażeń w klinikach Europy - perspektywy i koncepcje poprawy jakości. Aseptyka. 2004;2:8-11.

19. Boer AS. Monitorowanie zakażeń miejsca operowanego w Holandii i Europie. Pielęg Epidemiol. 2003;7(15):13.

20. Wieder-Huszla S, Jurczak A, Grochans E, et al. Występowanie zakażeń wśród pacjentów po zabiegach operacyjnych przebywających w oddziale intensywnej terapii. Probl Hig Epidemiol. 2012;93(3):586-92.

21. Pierzchała K, Bogoniowska-Fahie A, Jakubowski A, et al. Porównanie wykrywalności zakażenia miejsca operowanego w metodzie biernej i czynnej rejestracji zakażeń szpitalnych. Zakażenia. 2003;4:15.

22. Reed D, Kemmerly SA. Infection control and prevention: a review of hospital-acquired infections and the economic implications. Ochsner J. 2009;9(1):27-31.

23. Pournoor J. Nowe narzędzia naukowe służące lepszemu zrozumieniu metod postępowania aseptycznego. Pielęg Epidemiol. 2004;4(19):9-12.
Corresponding author

Dr n. med. Marek Kos

13 Chopina Str., 23-200 Kraśnik

tel. 695-330-700

E-mail: marekkos@op.pl 